\title{
Tradición literaria en el imaginario poético de Felipe Godínez: dos topos recurrentes en su teatro*
}

\author{
Esperanza Rivera Salmerón \\ Universidad de Valladolid \\ esperanzamaria.rivera@uva.es
}

Recepción: 15/09/2019, Aceptación: 24/03/2021, Publicación: 22/12/2021

\section{Resumen}

El presente trabajo se propone estudiar dos de los símbolos que hallamos con mayor recurrencia en la obra de Felipe Godínez (1582-1659), dramaturgo del Siglo de Oro cuyo teatro gozó de un importante éxito en las tablas del siglo xviI y que a día de hoy está concitando nuestra atención. Estudiaremos, en concreto, las metáforas náuticas y la imagen del olmo y la vid en algunas de sus comedias - tanto religiosas como profanaspara poder demostrar que ambas alegorías, recogidas en emblemas de Andrea Alciato, se configuran como parte esencial del imaginario poético del dramaturgo.

\section{Palabras clave}

Felipe Godínez; teatro barroco; imaginario poético; metáforas náuticas; el olmo y la vid; Andrea Alciato.

\begin{abstract}
English Title. Literary tradition in Felipe Godinez's poetic imaginary: two recurring topoi in his theater.

This paper aims to study the two topics that appear more frequently in the Felipe Godínez's work (1582-1659), a playwright from the Golden Age whose theatrical pieces enjoyed great success on stage during the 17 th century and is attracting our attention today. We will study in detail the nautical metaphors and the image of the elm and the vine in some of his comedies -religious and profane- to show that both allegories, depicted in emblems of Andrea Alciato, are key elements within the poetic imaginary of the playwright.
\end{abstract}

\section{Keywords}

Felipe Godínez; baroque theatre; poetic imaginary; nautical metaphors; the elm and the vine; Andrea Alciato. 
Felipe Godínez (1582-1659), poeta y dramaturgo nacido en Moguer (Huelva), vivió a caballo entre la época de Lope de Vega y la de Calderón de la Barca; contemporáneo, pues, de Vélez de Guevara, Tirso de Molina y Ruiz de Alarcón. Precisamente por ser considerado un autor "menor", "de segunda fila" respecto a los grandes creadores del teatro barroco, durante mucho tiempo ha sufrido un abandono prácticamente absoluto por parte de la crítica. Con algún trabajo testimonial a finales del siglo XIX, no será hasta la década de los setenta del siglo xx cuando la figura y obra de Felipe Godínez comiencen a ser objeto de un estudio amplio y serio. En este sentido, es reseñable la publicación de una serie de trabajos dedicados a su biografía, muy interesante por su condición de converso y por su comparecencia en un auto de fe en 1624 acusado de "hereje" y "judaizante"; asimismo, destacan otros centrados en su producción dramática, la cual está formada — según las últimas investigaciones - por veintiuna comedias de autoría segura, quince religiosas y seis profanas; a estas investigaciones han seguido otras que continúan hasta nuestros días. ${ }^{1}$

Everet W. Hesse (1968: 15), en su célebre estudio Análisis e interpretación de la comedia, reflexiona acerca de la importancia que tiene ahondar en el imaginario poético de los dramaturgos áureos, los cuales se sirven - como todo escritor- de una serie de metáforas, alegorías o símbolos que suelen ser recurrentes en sus obras. Estos, claro está, forman parte del bagaje cultural y literario del autor, y, según sea su intención en cada momento, reflejarán matices diferentes:

Una de las primeras tareas del investigador es examinar la agrupación de las imágenes. Muchas veces el autor emplea la técnica de reforzar su significado con el uso de la redundancia y la agrupación de imágenes. Al mismo tiempo que hace el dramaturgo una comparación, hace también un contraste que tiene el efecto paradójico de señalar diferencias y semejanzas para aumentar el impacto emocional. Por la economía del tiempo en el drama, no se pueden malgastar palabras. El autor debe sacar de ellas cada matiz posible de significado.

Fijar algunos de los topoi que se repiten frecuentemente en bastantes de las piezas de Felipe Godínez nos permitirá acercarnos al repertorio simbólico y conceptual que manejaba el autor para representar temas tan universales como el

1. Este artículo se publica en el marco del Proyecto de Investigación "De Antonio Enríquez Gómez a Fernando de Zárate: obra dramática y ensayos políticos” (FFI2017-87523-P), financiado por el Ministerio de Ciencia, Innovación y Universidades.

Véase el estado de la cuestión llevado a cabo por Menéndez Onrubia (2009). Además, hemos de añadir estudios posteriores y determinantes como los de Vega (2009a, 2009b), y los de SánchezCid, entre los que destacamos el más reciente de 2016. Asimismo, puede consultarse el Portal dedicado al dramaturgo en la Biblioteca Virtual Miguel de Cervantes: http://www.cervantesvirtual.com/portales/felipe_godinez/ o el reciente monográfico (2017) publicado también sobre el autor y aspectos interesantes de su obra en la revista electrónica norteamericana eHumanista: http://www.ehumanista.ucsb.edu/conversos/5. 
amor, la duda, el poder, la relación paterno-filial, la amistad, la fortuna, etc. Según nuestras investigaciones, algunas de estas imágenes se corresponden con las más clásicas de la historia de la literatura: la mariposa y la llama, símbolo del amor irrefrenable; la noria de la fortuna, representante de la cambiante suerte que experimentan los personajes; las metáforas náuticas, fuente de variadas interpretaciones, entre la que destaca como alegoría de las dudas amorosas; o la imagen del olmo y la vid, tradicionalmente utilizada para reflejar la unión amorosa o de amistad. En este trabajo estudiaremos únicamente las dos últimas, cuya unión aquí se explica por su doble condición "emblemática": se convierten, como veremos, en divisas esenciales del lenguaje poético del onubense y mantienen una íntima relación no únicamente con la tradición literaria clásica, sino también con algunos de los más conocidos emblemas de Andrea Alciato.

Debido a que la obra dramática del onubense no ha sido, por ahora y salvo algunas excepciones, editada modernamente, consideramos importante aportar a continuación los fragmentos que respaldan nuestra tesis, así como contextualizarlos con una breve introducción que nos sitúe en los albores de la enunciación de estos tópicos literarios. Aprovechamos asimismo para señalar que esta peculiaridad nos imposibilita, por cuestión de espacio, ofrecer un panorama detallado y completo del imaginario poético de Felipe Godínez, también necesario y pertinente en un autor tan desconocido, y que confiamos pueda realizarse en un corto plazo. ${ }^{2}$

\section{Metáforas náuticas}

Marinero soy de amor y en su piélago profundo navego sin esperanza de llegar a puerto alguno. (Miguel de Cervantes, Don Quijote de la Mancha, I, 43)

Las imágenes náuticas son tópicas en la historia de la literatura como símbolos de diferentes realidades que preocupan al poeta; así, es conocida la metáfora de la vida como una nave que transita por el mar, el cual puede estar en calma pero generalmente se mostrará impetuoso y hasta tempestuoso, con todo lo que ello significa; ${ }^{3}$ del mismo modo, es recurrente desde los clásicos la representación

2. Anotamos, no obstante, a continuación las comedias en que utiliza cada una de las imágenes citadas: la mariposa y la llama en Acertar de tres las una, De buen moro buen cristiano, Aun de noche alumbra el sol (de manera significativa en varias ocasiones), Cautelas son amistades y Los trabajos de Job; la noria de la fortuna, por su parte, en Amán y Mardoqueo, La reina Ester, Acertar de tres la una, Cautelas son amistades (utilizada en esta comedia como "noria del mundo" en la mayor parte de sus enunciaciones, expresión que parece original del moguereño según las investigaciones realizadas al respecto) y La paciencia de Job.

3. El tópico de la tormenta ha sido estudiado por Fernández Mosquera en varios trabajos exce- 
de la obra literaria, de la creación poética casi siempre, como un viaje marítimo, y así lo estudió el pionero Ernst Robert Curtius (1955: 189-193) en su clásica y aún valiosísima monografía; además, es frecuente la imagen del barco como símil del enamorado que es sometido a los embates de las tempestades del mar —el amor- imagen que en la literatura española tiene su ejemplo seguramente más célebre en las delicadas "barquillas" incluidas por Lope en su Dorotea $(1632)^{4}$ y que nos interesa especialmente porque es la que encontraremos con mayor frecuencia en los textos godinianos.

Esta última versión de la metáfora nos remite fundamentalmente a dos de los grandes poetas latinos: Horacio y Ovidio. El primero de ellos dice lo siguiente en la oda 14 del primer libro de sus Carmina (Horacio, Odas y epodos, 121122, en traducción de Fernández Galiano y Cristóbal):

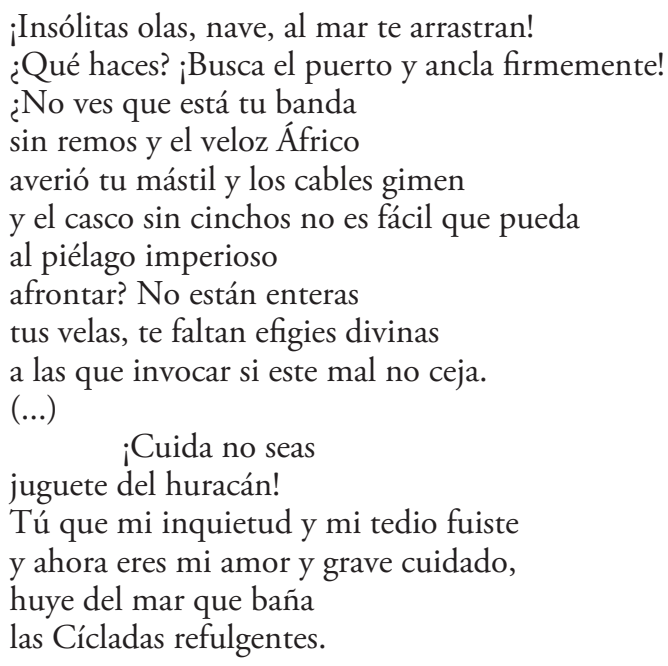

Es cierto que la teoría más difundida ha entendido alegóricamente esa nave que va a la deriva, y a la que se dirige el poeta con preocupación, como imagen del estado, de la república romana, desde que Quintiliano (Institutition Oratoi-

lentes dedicados a los grandes escritores del Siglo de Oro español: Lope de Vega (2002), Calderón de la Barca (2003) o Quevedo (2006a); de referencia es igualmente el monográfico publicado en 2006 (2006b), que presenta un estudio amplio sobre el tema de la tormenta en la literatura espańola y recoge y actualiza los estudios anteriores. Destaca, por último, otro trabajo suyo en el que analiza la presencia del tópico en el Persiles de Cervantes (2018).

4. Para profundizar en la presencia de este motivo en la poesía de los Siglos de Oro, véase Sarmati (2009). Es este un monográfico dedicado a naufragi e tempeste d'amore en autores como Ausiàs March, Juan Boscán, Garcilaso de la Vega, Hurtado de Mendoza, Gutierre de Cetina, Fernando de Herrera, Góngora, Lope o Quevedo, partiendo del eslabón fundamental que supuso Petrarca. Felipe Godínez se inserta, como estudiaremos a continuación, en esta nómina de escritores áureos que acuden a la archifamosa imagen literaria. 
re, VIII, 6, 44, 116-117) lo interpretara así: el barco sería la república, como decíamos; las tempestades de las olas un símbolo de las guerras civiles, y el puerto representaría la paz y la concordia. Pero también hay otra hipótesis, posterior aunque ya también tradicional, que defiende esa embarcación como una alegoría vital del propio Horacio, es decir, como imagen de su persona (véase, por ejemplo, Fraenkel 1980: 154-160), lo que se acercaría más a la lectura que encontramos en los textos de nuestro dramaturgo.

Más clara es, no obstante, la obra de Ovidio a la que atenderemos a continuación: Amores, II, 10, 9. En ella, el poeta confiesa que está enamorado de dos mujeres que poseen encantos semejantes, los cuales le impiden decidirse por una de ellas. Para expresar su dilema, utiliza una comparación marítima (vv. 9-10): "Errante voy igual que la chalupa / a la que empujan vientos en discordia, / y uno y el otro amor me tienen dividido" (Ovidio Amores. Arte de Amar, 248-249, en traducción de González Iglesias). Como explica Laguna Mariscal (1989: 310 ), el yo poético sería esa nave que se debate entre dos vientos enfrentados, los cuales, evidentemente, representarían a esas dos mujeres que ama el poeta. El citado estudioso explica en su artículo que el topos del amor como un mar tempestuoso es muy habitual en la poesía griega epigramática; y añade posteriormente cómo, en la literatura latina, esta imagen puede adquirir diferentes variantes: así, los vaivenes que padece el enamorado se reflejan en aquellos que soporta un barco - y el marinero que va en él — cuando sufre un naufragio; la desazón amorosa se equipara, en otros casos, con el oleaje marino; o también es recurrente que las andanzas amorosas se expresen a través de un viaje marítimo en el que la renuncia al amor (renuntiatio amoris) se suele comparar con el retiro definitivo del marinero que se ha salvado de un naufragio. Todas estas imágenes son recogidas en textos de poetas latinos como Catulo, Virgilio u Horacio (Laguna Mariscal 1989: 310-311).

Como señala este mismo investigador (Laguna Mariscal 1989: 313):

Hemos visto, pues, dos imágenes poéticas íntimamente relacionadas: la comparación de las zozobras amorosas con las del mar; y la imagen del retiro de una nave o marinero como expresión de renuntiatio amoris. La combinación de ambos elementos complementarios apunta a la existencia de un tópico literario, que bien podríamos bautizar como nauigium amoris.

Este nauigium amoris, con los matices que veremos a continuación, aparece en varios fragmentos de Cautelas son amistades (1630-1632), ${ }^{5}$ la primera comedia de Felipe Godínez en la que nos detendremos, considerada por la crítica palatina seria (Rivera Salmerón 2018: 597-605). En esta pieza lo encontramos

5. En la fechación de las comedias seguimos a Bolaños (1983) y/o Vega (1986). Todos los fragmentos de esta comedia serán citados a partir de la edición crítica de Rivera Salmerón (2018: 865-942). 
siempre en boca de la duquesa de Milán, la dama protagonista, quien se acoge a él para expresar las dudas que siente al tener que elegir entre dos hombres: Enrique (lo que le dicta la razón, pues es el heredero de la Corona de Nápoles, el único sobrino del Rey) y Carlos Colona (el hombre al que ama realmente, un simple soldado). La primera vez que lo encontramos es en un diálogo de la dama con su amiga Irene, quien la aconseja que dé su mano a Enrique (pues es su "igual”), a lo que la Duquesa responde lo siguiente:

Pero aunque es mi igual, podré

decirlo sin miedo, amiga:

cuando le voy a querer,

Carlos llega y me detiene;

no te espantes si me ves

detenida en virtud suya,

que quizá debe de ser

o flaqueza humana en mí

o fuerza divina en él.

Tendidas todas las velas, de la mesana al bauprés, hipogrifo de las aguas tan veloz pasa un bajel, a quien es espuela el Bóreas, que no se atreve a correr ni aun el mismo pensamiento una pareja con él, $y$ a quien el pez potentado del alto océano, a quien sirena del mar no puede la ballena detener, suele en su mayor violencia llegar un pequeño pez, que llaman rémora, y este, por no entendido poder de alguna virtud oculta, a despecho del tropel de tantos vientos y velas, las alas corta o los pies al marino hipocentauro, pues sin dejarle mover confunde el arte al piloto y el gobierno al timonel. Ves aquí un ejemplo, Irene, donde, aunque mal dibujé unas líneas o perfiles de mi fortuna cruel: ¿qué nave tan poderosa las velas tendió a merced 


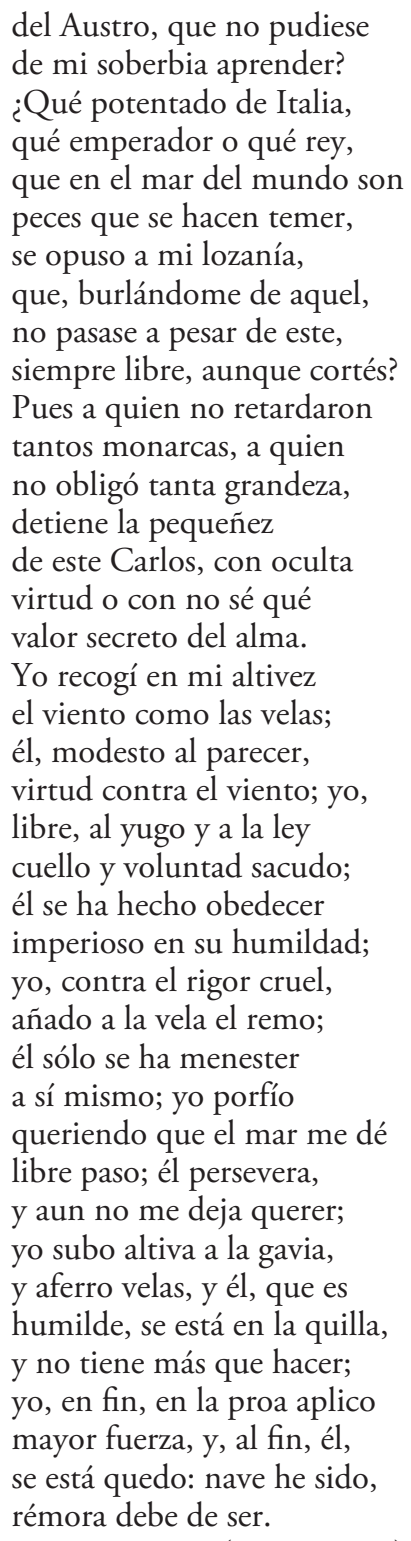

(vv. 899-977)

Como vemos, en este largo y poético parlamento la Duquesa se identifica con esa nave que quiere seguir el camino que más le conviene —el matrimonio con Enrique-, pero es incapaz de continuar por él porque es detenida en reiteradas ocasiones por un pez pequeño y de gran fuerza, la rémora, imagen del ser amado - Carlos- . En este caso, la tópica imagen de la navegación como símbolo del amante se une a otra que encontramos en uno de los emblemas de Al- 
ciato (Emblemas, 117-118), en concreto el LXXXII, que reza "Contra los que fácilmente se apartan de la virtud" (In facile a virtute desciscentes):

Así como una rémora pequeña como un caracol puede por sí sola detener una nave a despecho del impulso del viento y de los remos, así una causa insignificante detiene en mitad de su camino a algunos que se encaminan, por su ingenio y virtud, hacia los astros. Una querella angustiosa o la pasión por una puta es capaz de apartar a los jóvenes de los altos estudios. ${ }^{6}$

Es decir, la Duquesa es consciente de que, aunque Carlos sea pequeño, desigual a ella y humilde, tiene la misma fuerza que la rémora, quien es capaz de detener el avance de un navío en el mar. En cambio, ningún otro personaje de mayor rango social o de más poder ("pez potentado"), como podría ser en este caso Enrique, tiene la capacidad de hacerla vacilar en su pasión. Además de ser un discurso sobre sus dudas amorosas, es un bello alegato sobre su libertad: la Duquesa es un ser libre que está acostumbrada a tomar sus decisiones y nunca se ha encontrado con nadie, por mucho poder que tuviera, que consiguiera hacerla cambiar de parecer; ahora bien, el amor verdadero, que en este caso se corresponde con el de un humilde soldado, Carlos, ha logrado que esa libertad se vea mermada porque no puede seguir su rumbo en contra de su voluntad. En efecto, el amor la detiene, el amor la hace esclava de lo que siente, el amor consigue paralizarla contradiciendo a la razón.

Este conflicto que experimenta la dama es narrado por ella misma en tiempo real, pues, unos versos más adelante, cuando parece decidida a elegir al sobrino del Rey, vuelve a dudar ante la llegada, una vez más, de la rémora que detiene nuevamente "el bajel":

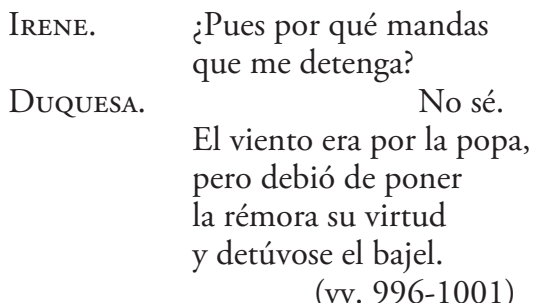

6. Más bella es, a nuestro modo de ver, la clásica versión de Daza Pinciano (1549: 72): “Como a una nao la Rémora detiene / menospreciados los remos y el viento, / ansí poca occasión a algunos tiene / a que no alcancen de virtud aumento, / como es un feo amor que no conviene, / o por razón de un pleito descontento, / que a los mancebos de índole excelente / estorba a que su sciencia se acreciente". 
Finalmente, se sobrepone y, recurriendo de nuevo a esa metáfora náutica, hace saber a Irene su intención de ser racional, práctica, y dejar de lado esos sentimientos que siente por Carlos, pues el barco tiene que ser más fuerte que las tormentas y que los vientos que se empecinan en hacerlo cambiar de destino. De nuevo hace explícitas su altivez, su soberbia y su valía como mujer decidida, inteligente y libre:

DuQUeSA.
Trocose el viento y ya es
por la proa. Lo que puedo
es procurar no volver
muchas jornadas atrás
porque me gobernaré
por la razón, que es el norte
viendo quién soy, y también
las dos coronas que gano;
y así, para no ofrecer
la mano a Carlos en medio
de golfo tan infiel,
el viaje se suspenda,
eche las áncoras, dé
fondo la nave fiada
por uno y otro escobén
a dos tan fuertes amarras
de decoro y de interés,
de modo que entre las olas
con repetido vaivén
resistiendo la tormenta,
que es lo más que puede hacer,
mientras ya sobre las nubes,
ya en los abismos se ve,
vacilando el frágil leño
está de mar en través.

(vv. 1019-1043)

Los criados de esta pieza también van a utilizar el lenguaje náutico en algunos de sus diálogos, conformando unas escenas paralelas que, con un tono más ligero, consiguen despertar en el lector/espectador una sonrisa. Es más, son precisamente ellos los primeros que hacen uso de esas imágenes, anticipando la que será una de las metáforas más recurrentes de la comedia. En el fragmento siguiente, Gandalín (donaire de la pieza) y Flora (criada de Irene) acaban de presenciar el primer encuentro de Carlos el Conde —el otro galán de la comedia y supuesto hermano de Carlos Colona- e Irene, entre los que se ha producido un

7. Buena parte de esta intervención de la dama está construida con una serie de encabalgamientos que la dotan de un ritmo que parece mimetizar precisamente el vaivén de un barco en alta mar. 
acercamiento amoroso. Una vez que estos salen de escena, los criados mantienen una conversación que empieza de esta manera:

GandaLín. El amorcillo es sutil.

FLORA. El escudero es notable.

GANDALín. Mi mesura está en un tris: ríndome, que el más señor suele humanarse y vivir. ¿Oye, señora fregata?

Flora. Oigo, señor bergantín.

GANDALín. Entrambos somos bajeles que al mar nos podemos ir.

(vv. 496-504)

Gandalín hace por primera vez referencia a un elemento náutico, la "fragata", término que, según lo utiliza él, como "fregata”, le permite también bromear con el significado de "fregona", es decir, de 'criada'. Ahora bien, lo interesante es que Flora le responde siguiéndole la gracia y denominándole "bergantín”, un tipo de buque cuyo nombre, a su vez, remite a la voz "bergante", es decir, 'pícaro', e incluso puede llegar a recordar otras palabras italianas como "brigante" ('bandido') y "birbante”, que significa 'bribón', lo mismo que "fregata” puede verse también como italianismo (repárese en que la acción se desarrolla en Nápoles y que ambos criados emplean en ocasiones otros términos propios del italiano). Así mismo, notamos la dilogía que hay en "bajeles", la cual hace referencia a 'barcos' y a 'personajes de baja condición'. Ambos, pues, juegan con el doble sentido que les aporta el lenguaje náutico y hablan de ese emparejamiento que los permite ser dos personajes afines por su condición de criados; ese mar del amor, a su medida, también es para ellos.

Esta misma imagen la encontramos en otras piezas de Godínez; en concreto, en su comedia bíblica Amán y Mardoqueo (1644-1650) , en la que el Rey se dirige a Ester alabando su belleza, que no se marchita con el paso de los ańos ( $f$. B4). En este caso la nave aparece equiparada al sol, el cual, aunque parece que se pone cada día con rapidez, en realidad lo hace lentamente, como si fuera detenido por una rémora; el sol, la nave, es una metáfora de Ester, de su belleza, y esa lentitud con que parece que se esconde el astro es una alegoría del pausado paso de los años sobre su hermosura. Es, pues, una variante en la utilización de la metáfora, pero la imagen es la misma:

Como el sol eres, sin duda, porque el sol, divina Ester, aunque nace cada día, tiene inmortal la niñez

8. Citamos a partir del impreso R/22658 conservado en la Biblioteca Nacional de Espańa. 


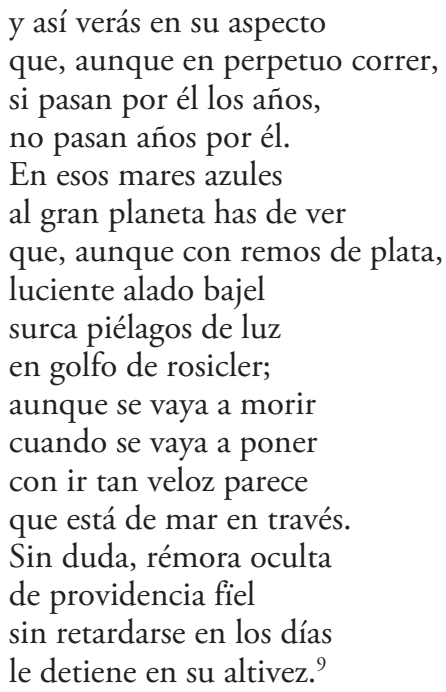

E incluso en la también bíblica Los trabajos de Job, ${ }^{10}$ donde el mismo Demonio nos declara, en un aparte, que él va a conseguir por todos los medios que Job termine desconfiando de Dios y perdiendo su fe; para ello, se sirve de la metáfora que hemos estudiado, en la que él es la rémora que detendrá esa nave, símbolo de Job:

Demonio. (¿Tanto de tu Dios confías?

Pues, yo, aquí sin que me veas, te detendré, porque seas, en golfo de envidias mías, tú un galeón, que fiel surcas tanto mar de miedo, y yo, rémora que puedo detener tanto bajel.)

(vv. 1611-1618)

Pero, además, en otras comedias utiliza imágenes marítimas en las que el barco adquiere otros significados, siempre, no obstante, vinculados a la tradi-

9. Hemos corregido un par de erratas que presentaba este fragmento en el impreso para ofrecer una lectura clara: en el que correspondería al verso 14 de este pasaje, encontramos "el golfo" (enmendamos por "en golfo"), y en el último verso "se detiene" (que subsanamos por "le detiene"). En ambos casos para devolverle a los versos el sentido que, a nuestro parecer, no tiene en el citado impreso.

10. Citamos todos los fragmentos a los que remitimos a través de la edición de Bolaños y Piñero (1991: 163-244). 
ción literaria. La segunda jornada de la comedia palaciega Acertar de tres la una (1626-1630) ${ }^{11}$ termina con un parlamento de Leonor, la dama protagonista, en el que, a través de la imagen del "frágil leño", muestra sus dudas sobre la situación que está viviendo: su marido, don Jaime, se ha batido en duelo con otro galán, don Diego, aunque ella duda si el enfrentamiento ha sido con él o con don Lope, a quienes todos quieren culpar y que es el hombre al que ella ama en realidad; tampoco sabe la dama si su marido ha resultado muerto. Su intervención nos recuerda en cierto modo a aquel que protagonizaba la duquesa de $\mathrm{Mi}$ lán en Cautelas son amistades al tener que debatirse entre el amor y la razón, aunque en este caso es el honor de su familia, el suyo y el de su marido, lo que está en juego, y perdemos la referencia a la rémora que en los ejemplos anteriores nos remitía a Alciato. Veámoslo a continuación:

LEONOR. Fuese y no me habló, bien hizo, que es la ocasión peligrosa, y para haberle olvidado aún es muy temprano ahora.

¿Si desafió con celos don Lope a don Jaime? Absorta la razón en tantas dudas discurrir apenas osa. No será, pero si fuese en contienda tan dudosa de respetos, ¿qué hará un alma impaciente, si no loca? Jaime es mi esposo, y amarle es deuda de honor forzosa cuando don Lope refiere nuestras pasadas memorias. ¡Oh, en cuántos mares me anego! ¡Oh, en cuánto abismo se engolfa, frágil leño, la paciencia, surcando agravios por ondas, y a los embates se entrega y a los peligros se arroja! Después que esperanza inútil llevó las áncoras todas, velas de cuidados tiende que las izan las congojas y las aferran los cabos. $¡ O h$, fines de antiguas glorias! Ya pierde de vista el puerto de tu quietud la memoria, mientras nubes de tristezas

11. Citamos a partir del impreso $T / 55344 / 5$ conservado en la Biblioteca Nacional de España. 


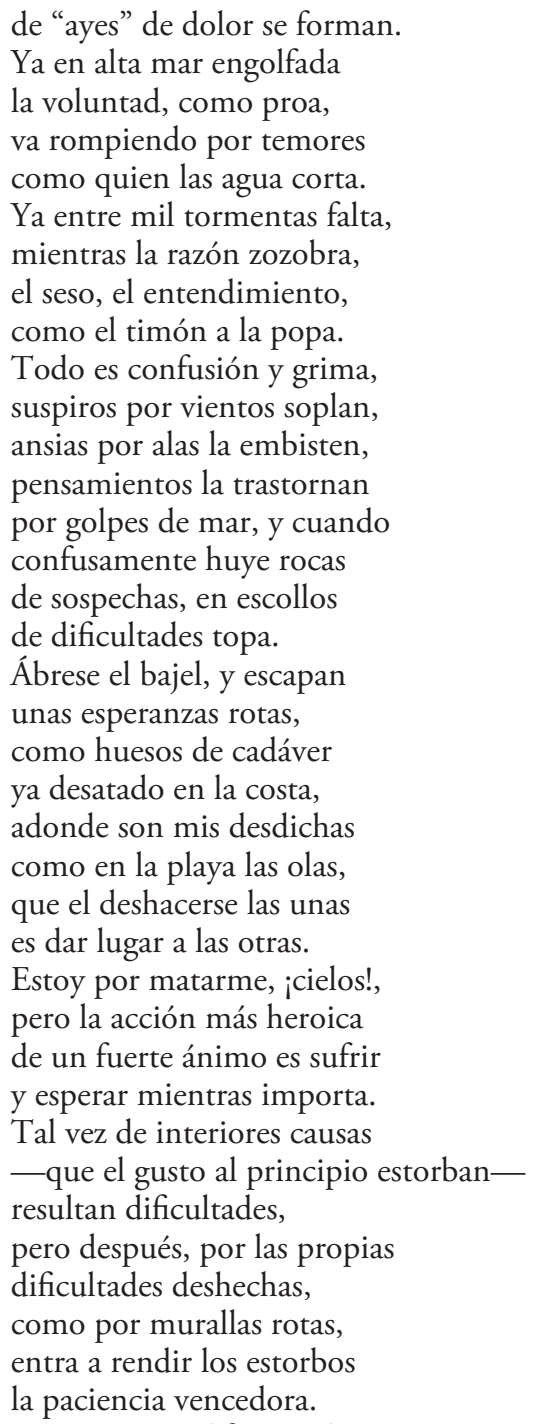

(ff. 21-22)

Como decíamos, la metáfora náutica le sirve para expresar sus dudas en torno a lo que está sucediendo, donde la razón zozobra ante los interrogantes que la atenazan, al igual que la embarcación que está "en alta mar engolfada", a la deriva por culpa de las tormentas, y que ha perdido de vista el puerto: "Todo es confusión y grima / suspiros por vientos soplan, / ansias por alas la embisten, / pensamientos la trastornan / por golpes de mar..." (f. 21). Confía, no obstante, Leonor en que con paciencia y esperanza saldrá victoriosa, como así podremos confirmar al final de la comedia. 
En la pieza palatina Aun de noche alumbra el sol (1630-1633) ${ }^{12}$ la variante que encontramos es de gran interés porque representa la unión amorosa remitiendo a la conjunción que se da entre el marinero y su nave. Así, Sol se dirige a Don Jaime, amigo íntimo de su esposo, Don Juan, en una extensa disertación (vv. 743-769) en la que intenta hacerle comprender que si su marido ha de marchar a otro lugar, porque el Rey así lo quiere, ella irá con él: "Pues, Don Jaime, yo y Don Juan, / en dos almas que son una, / somos nave y marinero / que en tanto golfo fluctúa" (vv. 767-770), y termina diciendo: "porque no le he de dejar / hasta que en igual fortuna / las rocas me hagan pedazos / o los abismos me hundan” (vv. 766-769). Es decir, ella está dispuesta a encontrar la muerte, si es necesario, pero no quiere separarse de él, como — entiende- el marinero no ha de abandonar nunca su nave; en esa reminiscencia del tópico que estamos estudiando, la renuntiatio amoris es una opción que la joven enamorada no contempla.

Por último, en otra pieza de género palatino, Basta intentarlo (1635-1637), ${ }^{13}$ Doña Blanca aconseja a su prima Dońa Elvira que no se deje cortejar por los dos galanes que la rondan, Tello y el Conde, pues posiblemente solo quieran divertirse con ella y su virtud está en juego. De nuevo se presenta el barco como imagen de la dama, a quien se advierte, antes de que el amor pueda conquistarla, de los muchos peligros que este sentimiento —al igual que el mar — trae consigo:

Huye, pues, de ambos escollos,
y teme que si te engolfas
en los riesgos del amor,
podrás perderte en la costa
de algún favor, porque Elvira,
aunque haya damas dichosas
que, agradecidas, escuchen
y, obligadas, correspondan
sin ofensa de su honor,
muy neciamente a las olas,
crédula nave se fía,
que si muchas van y tornan,
también se han perdido muchas
por la dicha de las otras.

En suma, podemos decir que las metáforas náuticas son muy repetidas en la producción dramática de Felipe Godínez, el cual, sirviéndose del tópico del nanigium amoris - ya sea en toda su amplitud o solo en alguna de sus manifestaciones-, del emblema de la rémora de Alciato y de imágenes de la nave como símbolo de las dudas que experimenta el enamorado ante diversas situaciones,

12. Citamos a partir de la edición de Bolaños y Piñero (1991: 75-162).

13. Citamos por el impreso $T / 55344 / 18$ de la Biblioteca Nacional de España. 
va conformando un lenguaje retórico interesante que se configura como un sello personal que encontramos, como un continuum, en comedias de diferentes subgéneros dramáticos, y en boca de personajes de todo tipo, como hemos visto de forma especial en Cautelas son amistades.

\section{El olmo y la vid}

Permite que yo sea el olmo desa vid, y que con lazos, dándote mil abrazos, tejida en laberintos mil te vea. (Francisco de Quevedo, “A una dama hermosa y borracha”)

Otra de las metáforas de las que se sirve Felipe Godínez para reflejar la unión en las relaciones humanas, ya sean amorosas o de otra índole, es la imagen clásica y tradicional del olmo y la vid, que tiene sus precedentes grecorromanos en Virgilio, Catulo y la Antología griega, y cuya imagen se hizo especialmente célebre muchos siglos después gracias al emblema CLX de Alciato, que reza "La amistad que dura aun después de la muerte" (Amicitia etiam post mortem durans) y en el que la pictura representa un olmo viejo al que la vid se anuda rodeándolo. El pie suscribe (Alciato, Emblemas, 201-203):

A un olmo seco por la vejez y desnudo de hojas, se ha abrazado una vid de espeso y verde follaje. Ella reconoce las vicisitudes de la naturaleza y devuelve a su padre los servicios que él ha prestado anteriormente. Con este ejemplo se nos advierte que busquemos unos amigos tales que no nos falte socorro en el día supremo. ${ }^{14}$

La historia de esta metáfora se analizó en un artículo ya célebre de Aurora Egido (1982), al que remitimos para profundizar en ella y desarrollar los puntos que trataremos con posterioridad. En él se pone de manifiesto el amplio abanico de significados que puede adquirir dicha imagen en los diferentes textos literarios en los que aparece, pues tiene la capacidad de adaptarse a distintos contextos, entre los que destaca su empleo como símbolo del vínculo sagrado de amistad, lectura que recoge el emblema de Alciato, pero también

14. Recogemos, de nuevo, la bella traducción de Daza Pinciano (1549: 31), que dice: "Al olmo viejo, seco y sin verdura, / la parra fresca y verde entretexida / es encubierto exemplo en tal figura / que al' amistad durable nos conbida. / Pues no es perfecto amor el que no dura / al menos hasta el ir de aquesta vida. / Bueno será buscar amigos tales / que quedos siempre estén a nuestros males." 
de esa íntima relación que se da entre los enamorados (con su matiz de erotismo en muchas ocasiones).

El porqué de la unión de estos dos tipos de árboles la encontramos tanto en su origen real como en la tradición mitológica. Por una parte, está ampliamente documentado en la viticultura antigua (las Geórgicas de Virgilio o el De agricultura de Columela, por ejemplo) que el olmo (e incluso otros árboles similares) se empleaba para hacer crecer las ramas de la vid en torno a su tronco y facilitar así las tareas vitícolas, como la poda y la vendimia, actuando el árbol a modo de espaldera. En cuanto a su tradición mitológica, la vid (como la hiedra) tiene un carácter lujurioso, mientras que el olmo (equiparado en algunos textos al álamo) se concibe en relación con rituales de fertilidad y con la tradición homérica; además, frente a la vid, es símbolo de masculinidad. De forma genérica, además, el árbol es imagen de la vida y de la inmortalidad ya en la mitología oriental, al igual que en la tradición cristiana desde el Génesis. Uno de los símbolos más extendidos, por tanto, es la equiparación del hombre a un árbol.

Así pues, como bien dice Egido (1982: 218), "el vínculo del olmo y la vid aparece como dictado perenne de la unión que supera a la muerte, pues es capaz de reanimarlos en su mutua convivencia”, imagen trascendental que será especialmente reiterada en la literatura. Dentro de la española, destaca la Égloga I de Garcilaso como el texto en el que se acrisola el motivo, y después será un tópico en toda la poesía de los Siglos de Oro, sobre el que dice Cull (2000: 590-591): "Se trata más bien de una imagen poética de la lascivia muy frecuente de casi todos los poetas del periodo", afirmación con la que no estamos de acuerdo totalmente, puesto que en muchos textos adquiere diferentes significados que se alejan de lo erótico. Por citar algunos poetas de la época, destacaremos a los hermanos Argensola, Francisco de Rioja, Figueroa, Francisco de la Torre, ${ }^{15}$ Villamediana, Juan de Arguijo, Guillén de Castro, Soto de Rojas, Lope de Vega, Góngora ${ }^{16}$ y, por supuesto, Quevedo, a quien Egido (1982: 227-232) dedica gran parte del sobredicho estudio.

Centrándonos en la producción godiniana, veremos cómo el dramaturgo onubense utiliza esta imagen en varias de sus comedias, otorgándole, además, en la ya citada Cautelas son amistades un significado que no hemos encontrado en otros textos: el amor existente entre un padre y un hijo, que en el caso de nuestra

15. Poeta en que el topos es especialmente relevante como adorno del reiterado locus amoenus que se dibuja en su poesía; además, se trata desde diferentes e interesantes perspectivas. Para profundizar en él, véase Orobitg (2001).

16. Pérez Lasheras (2011: 150-166) dedica un capítulo muy interesante de su edición de la Fábula de Píramo y Tisbe a esta imagen emblemática, en el que, además de estudiar con detención su significado en la pieza gongorina (y haciendo calas en otras obras relevantes del escritor cordobés, como el Polifemo o las Soledades), añade una serie de autores pocos citados por la crítica que también dedican espacio en sus versos a esta imagen que estamos estudiando; estos son Bocángel, Castillo Solórzano, Diego Ramírez Pagán o Antonio Carrillo de Mendoza. 
comedia se evidencia en la secreta (y por ellos ignorada) relación paterno-filial entre Carlos el Conde y el Rey. Sobre ella habla el joven galán con Irene en un bello pasaje que reproducimos a continuación, en el que le explica cómo ha sido el encuentro con el Monarca durante el cual ha sido nombrado Conde:

En fin, el Rey me abrazó, $\mathrm{y}$ aunque ya puede vivir muy poco por ser muy viejo, nueva vida le añadí.

Figurad un olmo anciano ya incapaz de digerir el alimento robusto que da la tierra de sí, tanto, que apenas viviente, por la ya flaca raíz bebe humor con que no acaba de secarse y de morir; si a este olmo antiguo le plantan al pie generosa vid, ella, que en el noble arrimo suele crecer y subir, le enlaza, y él, que se abriga con abrazo tan feliz, ya que no propio, prestado, tiene verdor juvenil: tal nuestro anciano Monarca pudo a sus pies advertir las esperanzas de un joven, que, aunque florecientes, vi que yacían por el suelo, mas levantome a ceñir su pecho, y a tal Alteza abrazándole subí, que él se gozaba en mi abrazo y yo en su arrimo, y, en fin, como si mi padre fuera, quedando entrambos allí estrechamente abrazados, él fue olmo y yo la vid: yo me sustentaba en él, y él se remozaba en mí. (vv. 439-474)

En Aun de noche alumbra el sol encontramos la metáfora para representar el amor entre Sol y Don Juan, pero haciendo una clara referencia a la antonomástica imagen de amistad. Veamos cómo expresa la dama esa indisoluble unidad que forman los enamorados: 
Sol. Imaginad — si no pierde quizás por muy repetida la comparación- ${ }^{17}$ asida a un olmo una yedra verde, que en recíproca amistad se unen los dos de tal modo, que en las partes de este todo no hay ya unión, sino unidad.

(vv. 2155-2162)

En De buen moro, buen cristiano (1626-1630), ${ }^{18}$ comedia hagiográfica, la metáfora se utiliza en dos ocasiones. En la primera de ellas, Gil, uno de los villanos de la comedia, se dirige a la joven Zaida para reiterarle lo bella que es, y la halaga de la siguiente manera:

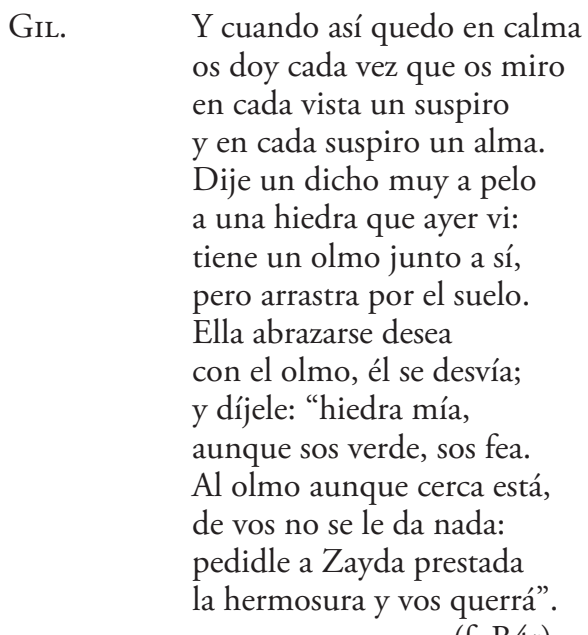

(f. B4r)

Utiliza Gil la fealdad de la hiedra para alabar la hermosura de la dama, quien debería prestar su belleza a esa planta para que pueda abrazarse al olmo, dándose, así, ese perfecto y tradicional maridaje del amor.

El otro ejemplo lo encontramos en un parlamento de Bartola, la villana compañera de Gil, la cual remite a la unión del olmo y la vid para referirse al amor que siente por Celio, con quien está dialogando. En realidad no habla explícitamente del olmo, pero se entiende que el árbol nuevo que sustituye al

17. Podríamos interpretar este inciso como un comentario del propio escritor, quien se mostraría consciente de lo muy manido que está el tópico a esas alturas y, en especial, también en su teatro, lo cual respaldaría nuestro estudio.

18. Citamos a partir del impreso R/11269 de la Biblioteca Nacional de España. 
tronco seco es ese olmo que, en síntesis con la vid, simboliza el verdadero amor. Bartola es la "bella mal maridada", la vid, y ese nuevo árbol que llega para abrazarla, el olmo, es Celio:

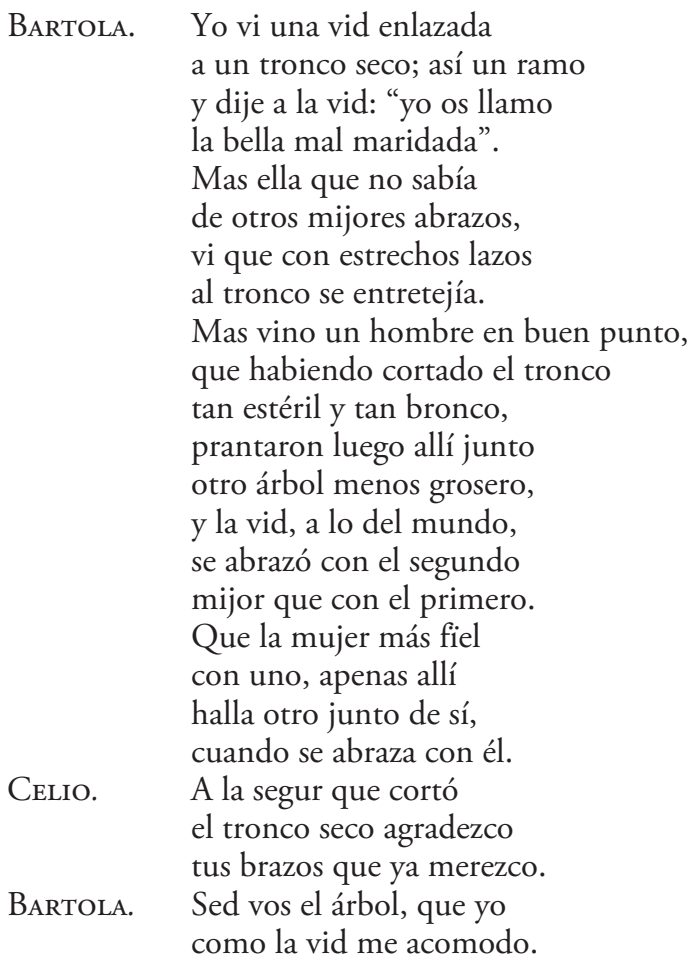

(f. D2v)

Al fin, en $O$ el fraile ha de ser ladrón o el ladrón ha de ser fraile (1640), ${ }^{19}$ también comedia de santos, retoma la tradicional variante del lascivo amor, aunque el personaje que utiliza la metáfora, Margarita, lo hace con un sentido muy particular: ella es tan sensual como la hiedra y tan pretendida (y "murmurada") como las lozanas hayas, pero sus encantos no serán disfrute de su interlocutor, Luquesio, sino que se reservan para el galán que ella ama:

\author{
MARGarita. ¿Ves esta lasciva hiedra, \\ que por falta de aquel olmo, \\ yace arrastrada, aunque muchos \\ le rogaran deseosos? \\ $¿$ Ves aquellas verdes hayas, \\ sobre aquel pradillo o folio
}

19. Citamos por el impreso 34071 de la Biblioteca de Menéndez Pelayo. 


\begin{tabular}{ll} 
& \multicolumn{1}{l}{ de esmeraldas, cuyas dichas } \\
murmuran tantos arroyos? & Pues yo soy por mis verdores \\
& haya, a quien murmuran todos, \\
& y hiedra para el cariño \\
& del nuevo galán que adoro. \\
LUQUESIO. & ¿Nuevo galán? \\
MARGARITA. & Y muy nuevo. \\
LUQUESIO. $\quad$ ¡Oh, qué grosero es el tronco, & que se ha negado a tal hiedra!
\end{tabular}

Lo interesante, por tanto, de la utilización de esta metáfora por parte de Godínez reside en la variedad de significados que le otorga en sus comedias, entre las que, como ocurría con la metáfora náutica, encontramos distintos tipos genéricos e, igualmente, el motivo toma voz en personajes de clases sociales muy diversas (desde un Conde hasta una pareja de villanos). El onubense parte de la tradición pero innova en cierta medida su tratamiento, destacando en este sentido el novedoso valor que adquiere en Cautelas son amistades, en la que la unión del olmo y la vid se erige como el amor puro que se da entre un padre y un hijo. Podemos decir, pues, que esta imagen también se convierte en una de sus marcas de identidad y, por ende, en otro de los motivos más queridos en sus versos.

\section{Coda}

Dice Sarmati (2009: 9) en su introducción al citado monográfico dedicado al estudio de las metáforas náuticas unas palabras que compartimos absolutamente y que respaldan el estudio de las imágenes que hemos presentado en líneas anteriores:

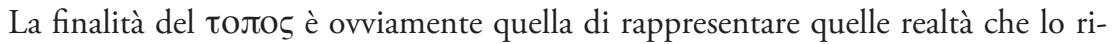
guardano. Il fatto stesso della ripetizione dice anche che per una ragione o per l'altra quel modo deve essere apparso in certi momenti il migliore per rappresentarla.

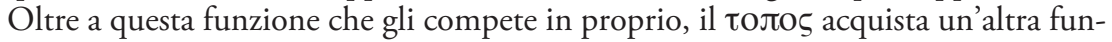
zione per rapporto alla catena informativa in cui è inserito; funge cioè da segnale per rapporto ad eventi che vengono narrati, a sentimenti che vengono evocati, a circostanze belle o brutte, buone o cattive che vengono descritte.

En efecto, los dos tópicos que hemos estudiado responden a esta afirmación que sostiene Sarmati, puesto que ambos han sido utilizados por el dramaturgo para reflejar aquellas realidades que, en cada caso, quería presentar de manera poética, adaptándose para ello a diversas situaciones protagonizadas por personajes de diversa naturaleza, y con los que se han expresado sentimientos de diferente tipo: amor (erótico, platónico y filial), amistad, dudas, deseo. Así pues, como se ha tratado de mostrar, estas alegorías —que Felipe Godínez recoge del 
acervo cultural y literario - se configuran como una parte sustancial del lenguaje simbólico de su teatro, el cual anteriormente había sido únicamente estudiado de forma general por Bolaños (1983: 614-645) en su clásico trabajo sobre la dramaturgia del onubense. La citada estudiosa anotó al respecto:

Felipe Godínez, en la búsqueda de un lenguaje literario, al igual que sus contemporáneos, vuelve la vista atrás y se fija en imágenes literarias que en un período anterior ya abundaron en la literatura, por lo que son conocidas de sus espectadores. Estas imágenes las desarrolla hasta el punto de convertirlas en auténticas alegorías. En la mente de todos los predicadores - y Godínez era uno de ellos- debía de estar un tipo de comparaciones, muy propicias para convencer a una masa poco instruida, pero muy religiosa; me refiero a los temas sacados de la Sagrada Biblia, tales como los de la vid, el olivo, el olmo... En la pluma de Godínez todas adquieren vivacidad, colorido y veracidad, capaz de satisfacer al alma que duda ante la situación conflictiva (Bolaños 1983: 632).

Pero el interés de estas imágenes en Godínez no está únicamente en su capacidad de recurrir a la tradición, sino que el moguereńo les confiere, como hemos dicho, su impronta particular. No se circunscribe a acudir a la tradición bíblica o clásica: bebe también de la emblemática de Alciato (de los emblemas LXXXII y CLX, como se ha señalado) y, además, aporta algunos matices que no encontramos en las fuentes, como es la citada utilización de la imagen del olmo y la vid para aludir a la (en este caso secreta) relación paterno-filial. Encontramos, pues, en su teatro, puntos de originalidad que no habían sido notados previamente y que amplían ese abanico de significados y convierten a Felipe Godínez en digno continuador de la transmisión de estas tópicas metáforas, con las cuales él irá creando también en su obra un mundo poético concreto.

Es interesante notar, finalmente, que las imágenes estudiadas desfilan por comedias tanto religiosas, ya sean bíblicas (Amán y Mardoqueo y Los trabajos de Job) o de santos (De buen moro buen cristiano y $O$ el fraile ha de ser ladrón...), como profanas, de cuyo corpus de seis comedias cuatro de ellas han sido empleadas en este trabajo: Acertar de tres la una, Aun de noche alumbra el sol, Cautelas son amistades y Basta intentarlo. Esto pone de manifiesto la importancia del estudio de las comedias no religiosas — las menos atendidas por la crítica — en la conformación de ese imaginario poético que consideramos necesario rescatar para acercarnos a un autor que, aunque ya no marginado, sigue reclamando mayor atención. Menos significativo es que todas las comedias formen parte de la considerada segunda y prolífica etapa vital del autor: la que se desarrolló en Madrid (a partir de finales de 1624) después de su vida sevillana y tras haberse enfrentado al fatídico auto de fe, pero nos sirve para corroborar que es en ese periodo literario más fructífero - en el que destacan los años treinta del siglo XVII- cuando Godínez perfiló su identidad poética, de la que forman parte de manera especial los topoi estudiados. 


\section{Bibliografía}

Alciato, Andrea, Emblemas, ed. de Santiago Sebastián, Madrid, Akal, 1993. Bolaños Donoso, Piedad, La obra dramática de Felipe Godinez (Trayectoria de un dramaturgo marginado), Sevilla, Diputación Provincial de Sevilla, 1983.

-, y Pedro M. Piñero (eds.), Felipe Godínez, Aun de noche alumbra el sol. Los trabajos de Job, , Kassel-Sevilla, Edition Reichenberger-Universidad de Sevilla, 1991.

Cull, John T., "La presencia de la emblemática en algunas comedias del Siglo de Oro", en Del libro de emblemas a la ciudad simbólica: actas del III Simposio Internacional de Emblemática Hispánica: Universitat Jaume I, CastellónBenicàssim, 30 de septiembre, 1 y 2 de octubre de 1999, coord. Víctor Mínguez Cornelles, Castellón, Universitat Jaume I, 2000, pp. 587-602.

Curtius, Ernst Robert, Literatura Europea y Edad Media Latina, Ciudad de México, Fondo de Cultura Económica, 1955.

Daza Pinciano, Bernardino, Los emblemas de Alciato traducidos en rhimas españolas, Lyon, Por Mathia Bonhome, 1549.

Egido, Aurora, "Variaciones sobre la vid y el olmo en la poesía de Quevedo: "Amor constante más allá de la muerte", en Academia Literaria Renacentista, II. Homenaje a Quevedo, Salamanca, Universidad de Salamanca, 1982, pp. 213-232.

FERnÁNDEZ Mosquera, Santiago, "Lope y la tormenta: variaciones de un tópico", Anuario de Lope de Vega, VIII (2002), pp. 47-80.

-, "La tempestad en el teatro de Calderón: del texto a las tablas", en Teatro calderoniano sobre el tablado: Calderón y su puesta en escena a través de los siglos. XIII Coloquio Anglogermano sobre Calderón, Florencia, 10-14 de julio de 2002. Archivum Calderonianum, X, ed. M. Tietz, Stuttgart, Franz Steiner Verlag, 2003, pp. 97-128.

—, "El motivo de la tormenta: la transformación de la épica", La Perinola. Revista de investigación quevediana, X (2006a), pp. 87-104.

—, La tormenta en el Siglo de Oro: variaciones funcionales de un tópico, MadridFráncfort del Meno, Iberoamericana-Vervuert, 2006b.

—, "La tormenta en el Persiles: un tópico con inesperado valor estructural", en Doctos libros juntos. Homenaje al profesor Ignacio Arellano Ayuso, ed. V. Roncero López y J. M. Escudero Baztán, Madrid- Fráncfort del Meno, Iberoamericana-Vervuert, 2018, pp. 223-239.

Fraenkel, E., Horace, Oxford, Oxford Clarendon Press, 1980.

Godínez, Felipe, Famosa comedia Acertar de tres la una del doctor Felipe Godinez, Madrid, Biblioteca Nacional de España, T/55344/5.

-, Comedia famosa de Amán y Mardoqueo, del doctor Felipe Godínez, Madrid, Biblioteca Nacional de España, R/22658.

-, Basta intentarlo. Comedia famosa del doctor Felipe Godinez, Madrid, Biblioteca Nacional de España, T/55344/18. 
-, De buen moro, buen cristiano. Comedia famosa del doctor Felipe Godinez, Madrid, Biblioteca Nacional de España, R/11269.

-, O el fraile ha de ser ladrón, o el ladrón ha de ser fraile, del doctor Felipe Godinez, Santander, Biblioteca de Menéndez Pelayo, 34071.

—, Aun de noche alumbra el sol. Los trabajos de Job, eds. Piedad Bolaños Donoso y Pedro M. Piñero Ramírez, Kassel / Sevilla, Edition Reichenberger / Universidad de Sevilla, 1991.

-, Cautelas son amistades, ed. Esperanza Rivera Salmerón, en Las armas y las letras en el teatro clásico español. Estudio y edición crítica de Cautelas son amistades de Felipe Godinez, Tesis doctoral, Valladolid, Universidad de Valladolid, 2018, pp. 856-940.

Hesse, Everet W., Análisis e interpretación de la comedia, Madrid, Castalia, 1968.

Horacio, Quinto, Odas y epodos, ed. bilingüe Manuel Fernández-Galiano y Vicente Cristóbal, Madrid, Cátedra, 2007.

Laguna Mariscal, Gabriel, "El texto de Ovidio, Amores II, 10.9 y el tópico del nauigium amoris”, Emerita, LVII, 2 (1989), pp. 309-315.

Menéndez Onrubia, Carmen, "Estudios en torno a Felipe Godínez. Bibliografía siglos xx y xxi", Montemayor. Revista de la Cultura, Monográfico especial. 350 aniversario de la muerte del poeta y dramaturgo Felipe Godinez (septiembre de 2009), Moguer (Huelva), Fundación Municipal de Cultura de Moguer-Ayuntamiento de Moguer, 2009, pp. 26-32.

Orobitg, Christine, "La yedra en la poesía de Francisco de la Torre: simbología y autorrepresentación", en Actas del V Congreso Internacional Siglo de Oro (AISO). Münster, 20-24 de julio de 1999, ed. Christoph Strosetzki, Fráncfort del Meno-Madrid, Vervuert-Iberoamericana, 2001, pp. 942-953.

Ovidio, Publio, Amores. Arte de amar, ed. y trad. Juan Antonio González Iglesias, Madrid, Cátedra, 1993.

Pérez Lasheras, Antonio, Ni amor ni constante (Góngora en su fábula de Píramo y Tisbe), Valladolid, Universidad de Valladolid (Fastiginia, 5), 2011.

Quintiliano, Marco Fabio, Institutition Oratoire, trad. Jean Cousin, V, Libros VIII y IX, París, Sociètè d'edition "Les Belles Lettres", 1978.

Rivera Salmerón, Esperanza (ed.), Felipe Godínez, Cautelas son amistades, en Las armas y las letras en el teatro clásico español. Estudio y edición crítica de Cautelas son amistades de Felipe Godinez, Tesis doctoral, Valladolid, Universidad de Valladolid, 2018, pp. 856-940.

Sarmati, Elisabetta, Naufragi e tempeste d'amore. Storia di una metafora nella Spagna dei secoli d'Oro, Roma, Carocci, 2009.

SÁnchez-Cid, Francisco Javier, La familia del dramaturgo Felipe Godinez. Un clan judeoconverso en la época de la Contrarreforma, Huelva, Publicaciones Universidad de Huelva, 2016.

Vega García-Luengos, Germán, Problemas de un dramaturgo del Siglo de Oro. Estudios sobre Felipe Godinez, Valladolid, Universidad de Valladolid, 1986. 
—, "Un balance de la recuperación del legado vital y literario de Felipe Godínez", en Finis Vitae. Testamento y codicilo de Felipe Godinez (1-2 de diciembre de 1659), Moguer (Huelva), Sociedad Estatal de Conmemoraciones Culturales (SECC), 2009a, pp. 13-33.

-, "Sobre la singularidad vital y dramática de Felipe Godínez", Montemayor. Revista de la Cultura, Monográfico especial. 350 aniversario de la muerte del poeta y dramaturgo Felipe Godinez (septiembre de 2009), Moguer (Huelva), Fundación Municipal de Cultura de Moguer-Ayuntamiento de Moguer, 2009b, pp. 17-25.

- (dir.), Felipe Godinez. Página web (inaugurada en septiembre de 2012), Biblioteca Virtual Miguel de Cervantes, en línea, <http://www.cervantesvirtual. $\mathrm{com} /$ portales/felipe_godinez/>.

- (ed.), El dramaturgo judeoconverso Felipe Godinez (1582-1659), eHumanista Conversos, V (2017), en línea, <https://www.ehumanista.ucsb.edu/conver$\operatorname{sos} / 5>$. 